\title{
LIMNOLOGY AND WATER QUALITY IN AN URBAN WATERSHED IN NORTH PANTANAL
}

\author{
P. A. J. GOMES-SILVA*, S. D. LIMA, R. GOLIN, Z. M. LIMA, E. B. MORAIS and E. F. G. C. DORES \\ Universidade Federal de Mato Grosso \\ gestorambiental.paulo@gmail.com *
}

Article submitted in January/2016 and accepted in March/2016

DOI: $10.15628 /$ holos.2016.3235

\section{ABSTRACT}

Studies focused on limnology and quality of water bodies are essential to produce data that support the planning and management, diagnose the current situation and propose measures to minimize the possible negative impacts on water resources. The Tereza Botas creek drains the town of Poconé-MT, situated in the Pantanal border. In this sense, the objective of this study was to verify the variations in limnological characteristics along the longitudinal gradient and evaluate the water quality of the Tereza Botas watershed, identifying the impacts from anthropogenic activities of this important Pantanal
\end{abstract}

watershed. Four sampling points along the longitudinal gradient of the water stream have been defined, and physical, chemical and microbiological variables were analyzed. The results indicated that the changes in limnological and water quality derive from the riparian vegetation removal, erosion and discharge of sewage in natura. In addition, high density of $E$. coli was observed in most of the sampled points, demonstrating that the lack of proper sanitation as well as the presence of rudimentary cesspit are negatively affecting water quality in the headwaters region.

KEYWORDS: Pantanal, urban stream, water management.

\section{LIMNOLOGIA E QUALIDADE DA ÁGUA DE UMA MICROBACIA URBANA DO PANTANAL NORTE}

\section{RESUMO}

Estudos voltados para a limnologia e qualidade da água de corpos d'água são essenciais para gerar dados que subsidiem o planejamento e a gestão, diagnosticar a situação atual bem como propor medidas que minimizem os possíveis impactos negativos sobre os recursos hídricos. A microbacia do córrego Tereza Botas drena o município de Poconé-MT, porta de entrada do Pantanal. Nesse sentido, o objetivo deste trabalho foi verificar as variações das características limnológicas ao longo do gradiente longitudinal e avaliar a qualidade da água da microbacia do córrego Tereza Botas, identificando os impactos oriundos de atividades antrópica dessa importante microbacia Pantaneira. Foram definidos quatro pontos amostrais ao longo do gradiente longitudinal da microbacia, sendo analisadas variáveis físicas, químicas e microbiológicas da água. Os resultados indicaram que as alterações limnológicas e a qualidade da água são oriundas da supressão vegetal ripária, processos erosivos e lançamento de esgoto sanitário in natura. Além disso, foi constatada elevada densidade de E. coli na maioria dos pontos amostrados, demonstrando a ausência de saneamento básico adequado bem como a influência negativa de fossas rudimentares na qualidade da água na região de cabeceira.

PALAVRAS-CHAVE: Pantanal, córrego urbano, gestão dos recursos hídricos. 


\section{INTRODUCTION}

Pantanal is a flood plain that is subjected to a monomodal predictable flood pulse of low amplitude. However, the local flooding pattern is very variable due to different discharge patterns of the Paraguay River and its tributaries as well as the precipitation natural variations that occur among different years. Besides the flooding stress, the biota in the Pantanal is exposed to animals and plants in this important watershed have to adapt to an extended dry season (JUNK et al., 2011).

The Pantanal of Mato Grosso, which is localized in two Brazilian states, Mato Grosso and Mato Grosso, do Sul, and in parts of Bolivia and Paraguay, is an important freshwater reserve in the world. This seasonally flooded wetland, one of the biggest in the world, recognized as a Biosphere Reserve by UNESCO in 2001, houses a rich biodiversity, as much in species as in habitats and landscape (PERTEMANN, 2011; CUNHA and JUNK, 2011), becoming one of the most important Brazilian biome.

Poconé is a town of Mato Grosso localized in the North Pantanal that, similarly to many other Brazilian municipalities, presents several environmental problems related to the lack of urban infrastructure. Among the urban creeks in this town, the Tereza Botas stream stands up, once it was an axis where a small community grew along, in the $18^{\text {th }}$ century, forming the city of Poconé. The Tereza Botas creek, whose main use is domestic wastewater dilution, is the major tributary of the Guanandi River, which in turn, is a tributary of Bento Gomes River. The poor water quality of this creek is in part responsible for the deterioration of the water quality of Bento Gomes River, main source where water is collected for public supply of Poconé. Moreover, Bento Gomes River is also a tributary of Paraguay River, which is the main river that feeds the Pantanal.

Studies on water quality and limnology of surface waters are essential to produce data to subsidize the management of the water resources in the Pantanal region, in order to ensure the multiple uses required by its population.

In this sense, this study aimed at verifying the variations of limnologic characteristics and water quality along the longitudinal gradient of Tereza Botas creek in order to identify the impacts of soil use and anthropic activities in this important micro basin of the Pantanal floodplain.

\section{MATERIAL AND METHODS}

\subsection{Study area}

The study area localized in the city of Poconé, within the geographical coordinates $16^{\circ} 15^{\prime} 59.09^{\prime \prime}$; $56^{\circ} 39^{\prime} 23.57^{\prime \prime} \mathrm{W}$ and $16^{\circ} 14^{\prime} 48.39 " \mathrm{~S} ; 56^{\circ} 36^{\prime} 9.25^{\prime \prime} \mathrm{W}$, is considered the entry of North Pantanal (VEIGA e FERNANDES, 1991)and integrates the hydrographical region of Paraguay where is localized many riverheads that form the Paraguay River (CASARIN, 2007).

Poconé is $100 \mathrm{~km}$ far from the capital of Mato Grosso State, Cuiabá, possesses an area of $17,270.987 \mathrm{~km}^{2}$ and a population of 32,053 inhabitants (IBGE, 2010).

Figure 1 presents the localization and delimitation of the micro basin of the Tereza Botas Creek (CTB). 


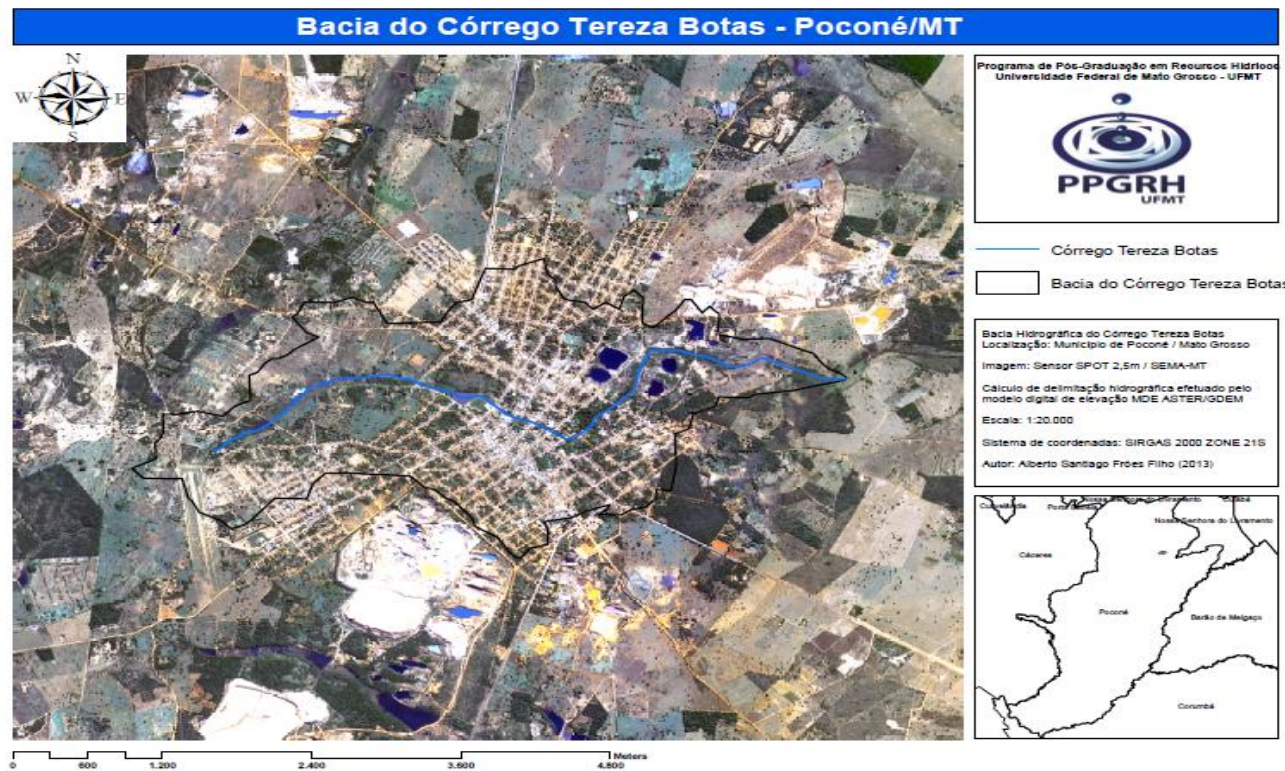

Figure 1 - Localization of Tereza Botas Creek micro basin Poconé - MT. Source: Fróes Filho (2013).

\subsection{Sampling}

Water samples were collected on Oct, 29 and Nov, 01 2013, in pre-selected points (Table 1; Figure 2). The samples were collected in triplicate in four points along the longitudinal gradient of the Tereza Botas Creek and were preserved and transported according the procedures described in the National Guide for Water Sampling and Preservation of the Environmental Company of São Paulo State (CETESB, 2011). The analytical methods followed the Standard Methods for the Examination of Water and Wastewater (AWWA-APHA, 2012).

Table 1 - Sampling points in Tereza Botas Creek, Poconé-MT.

\begin{tabular}{lc}
\hline \multicolumn{1}{c}{ Sampling points } & \multicolumn{1}{c}{ Geographical Coordinates } \\
\hline $\mathrm{P} 1$ - Headwater & $16^{\circ} 15^{\prime} 51.20^{\prime \prime} \mathrm{S} ; 56^{\circ} 38^{\prime} 54.00^{\prime \prime} \mathrm{W}$ \\
$\mathrm{P} 2$ - Tank Jurumirim & $16^{\circ} 15^{\prime} 40.54^{\prime \prime} \mathrm{S} ; 56^{\circ} 38^{\prime} 44.48^{\prime \prime} \mathrm{W}$ \\
$\mathrm{P} 3$ - Tank da Rua & $16^{\circ} 15^{\prime} 35.25^{\prime \prime} \mathrm{S} ; 56^{\circ} 37^{\prime} 52.10^{\prime \prime} \mathrm{W}$ \\
$\mathrm{P} 4$ - Mouth of the river & $16^{\circ} 15^{\circ} 23.27^{\prime \prime} \mathrm{S} ; 56^{\circ} 36^{\prime} 12.61^{\prime \prime} \mathrm{W}$ \\
\hline
\end{tabular}

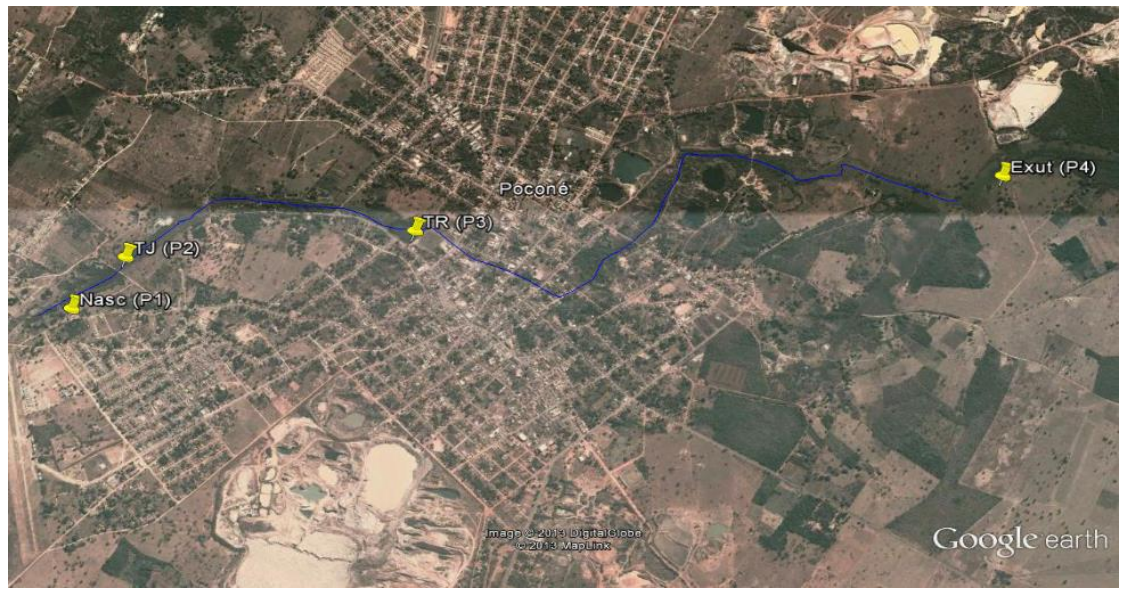

Figure 2 - Sampling points in Tereza Botas Creek. Source: authors (2013), adapted from Google Earth. 
P1 (Headwater) - The headwater of the Tereza Botas creek is localized near to illegal pottery enterprises and to the Poconé airport. In its surroundings, there are many rudimentary cesspits, which may reduce water quality. This area is greatly degraded and a downward movement of the water spring of the creek was observed. There are also intense erosive processes and a vegetable-garden in its surroundings.

P2 (Tank Jurumirim) - The Tank Jurumirim is situated upward downtown of Poconé, with few houses and small grasslands around it.

P3 (Tank da Rua) - This small dam is localized in the central area of the city. There is a water collection point for gardening irrigation and road cleaning. It receives untreated wastewater and rainwater from the higher part of the city.

P4 (Mouth of the river) - The point nearer to the mouth of the river (P4) is situated close to a gold mining area that collect water for rocks washing. Due to this collection from many mining sites in its course, this part of the creek is intermittent.

The physical, chemical and microbiological variables analyzed in the water samples from the Tereza Botas creek are described in Table 2.

Table 2 - Variables analyzed in Tereza Botas water samples

\begin{tabular}{|c|c|c|}
\hline VARIABLES & $\begin{array}{l}\text { EQUIPMENT/METHOD } \\
\text { (AWWA-APHA, 2012) }\end{array}$ & UN. \\
\hline Air temperataure & Mercury thermometer & ${ }^{\circ} \mathrm{C}$ \\
\hline $\mathrm{pH}$ & Potentiometer & ---------- \\
\hline Dissolved Oxigen & Oximeter & $\mathrm{mg} \cdot \mathrm{L}^{-1}$ \\
\hline Electrical Conductivity & Conductivimeter & $\mu S . \mathrm{cm}^{-1}$ \\
\hline Turbity & Turbidimeter & NTU \\
\hline True collor & Espectrophotometer & mgPT. $L^{-1}$ \\
\hline BOD & $\operatorname{BOD}\left(5,20^{\circ} \mathrm{C}\right)$ & $\mathrm{mg} \cdot \mathrm{L}^{-1}$ \\
\hline Total phosphorus (PT) & Potassium Persufate & $\mathrm{mg} \cdot \mathrm{L}^{-1}$ \\
\hline $\begin{array}{l}\text { Total coliform and } \\
\text { Escherichia coli }\end{array}$ & $\begin{array}{l}\text { Chromogenic/fluorogenic enzimatic substrate Colilert } \\
\qquad\left(\text { IDEXX }{ }^{\circledR}\right)\end{array}$ & $\mathrm{MPN} / 100 \mathrm{~mL}$ \\
\hline
\end{tabular}

\section{RESULTS AND DISCUSSION}

\section{$3.1 \mathrm{pH}$}

The hydrogenionic potential $(\mathrm{pH})$, according to Esteves (2011), interferes in many different ways in the aquatic ecosystem metabolism. Regarding the communities, $\mathrm{pH}$ acts directly on cellular membrane permeability, interfering in the intra and extracellular ion transport.

The CONAMA Resolution n. 357/2005 (BRASIL, 2005) establishes a range from 6.0 to 9.0 for $\mathrm{pH}$. Figure 3 presents the $\mathrm{pH}$ in the water samples from Tereza Botas creek. 


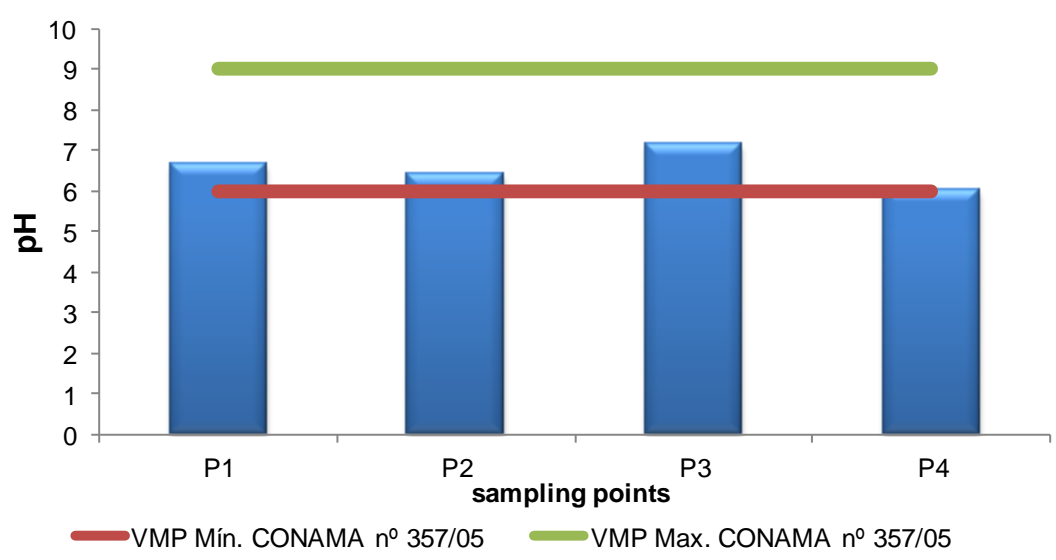

Figure 3-pH variation in water samples collected along the Tereza Botas creek, MT.

The values of $\mathrm{pH}$ ranged from 6.0 to 7.14 without a clear trend downward along the creek. All the points presented $\mathrm{pH}$ within the legal limits. This parameter is one of the most difficult to evaluate since several conditions such as hydrogeochemistry and organic matter decomposition, among others influence $\mathrm{pH}$. In general, changes in $\mathrm{pH}$ indicate alteration in the aquatic environment.

\subsection{Dissolved oxygen (DO)}

According to Esteves (2011), among the gases dissolved in water, oxygen is one of the most important to the dynamics and characterization of an aquatic ecosystem. The main sources of oxygen to the water are atmosphere and photosynthesis. The concentration of organic matter in water and high temperatures contribute to water desoxygenation. Figure 4 shows the values of DO in Tereza Botas creek.

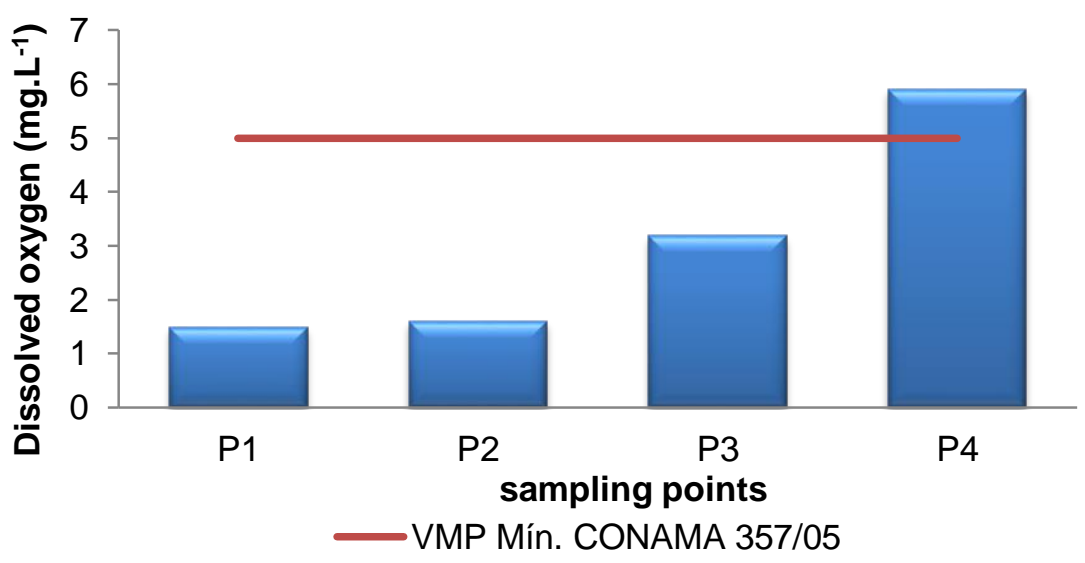

Figure 4 - Variation of dissolved oxygen in water along Tereza Botas creek, MT

The legal limit for dissolved oxygen in Class 2 rivers established in the Resolution CONAMA n. $357 / 2005$ (BRASIL, 2005) is $5.0 \mathrm{mg} \cdot \mathrm{L}^{-1}$

Except for point P4, all the others were lower than the legal limit of $5.0 \mathrm{mg} . \mathrm{L}^{-1}$, varying from 1.49 to $5.90 \mathrm{mg}$. $\mathrm{L}^{-1}$. The periodic lack of water flow and the high organic matter content explain the low OD concentration in points P1, P2 and P3. At P1, the low OD is related to the reduced flow 
and at the sampling time a smell characteristic of domestic sewage was felt, what was confirmed by the high concentration of Escherichia coli (E. coli). Points P2 and P3 are lentic ambient and the very low water flow at the beginning of the raining period explains the low OD. In addition, the considerable presence of color, turbidity and aquatic macrophytes, which reduce the gas exchange at the water surface and the photosynthesis, contributed to these results.

On the other hand, the higher OD content at P4 may be related to the presence of water flow as a consequence of groundwater disposal at the river by a mining company localized upward this point.

\subsection{Total phosphorus (PT) e Total Kjeldahl Nitrogen (TKN)}

Organic phosphorus and phosphate are parameters that express the amount of nutrients available to biological processes (Silveira, 2009). Phosphorus may occur in water in three different forms: organic, orthophosphate and polyphosphate (Von Sperling, 2014). This element may be of natural origin by dissolution of soil compounds, cellular decomposition of microorganisms and decomposition of organic matter and of anthropogenic origin from domestic and/or industrial, animal excrements or phosphate fertilizers. .

Nitrogen, according to Von Sperling (2014), occurs in several forms and oxidation states, and may be found in the water as molecular nitrogen $\left(\mathrm{N}_{2}\right)$, organic nitrogen, ammonium, nitrite and nitrate. Worth mentioning that Esteves (2011) states that the main inorganic form that is readily available to metabolic processes is the ammonium ion $\left(\mathrm{NH}_{4}{ }^{+}\right)$. The total nitrogen Kjeldahl (TKN) represents the sum of organic nitrogen and ammonium.

Moreover, according to Von Sperling (2014), phosphorus and nitrogen are indispensable elements for the algae growth, and that when present in high concentrations (high nutrient content) they are responsible for the artificial eutrophication of the water body. Esteves (2011) pointed out that this phenomenon can be considered a chain reaction of causes and effects, whose main characteristics is the relative disruption of the ecosystem stability, called homeostasis. Figure 5 shows the concentrations of total phosphorus and TKN in the Tereza Botas creek.

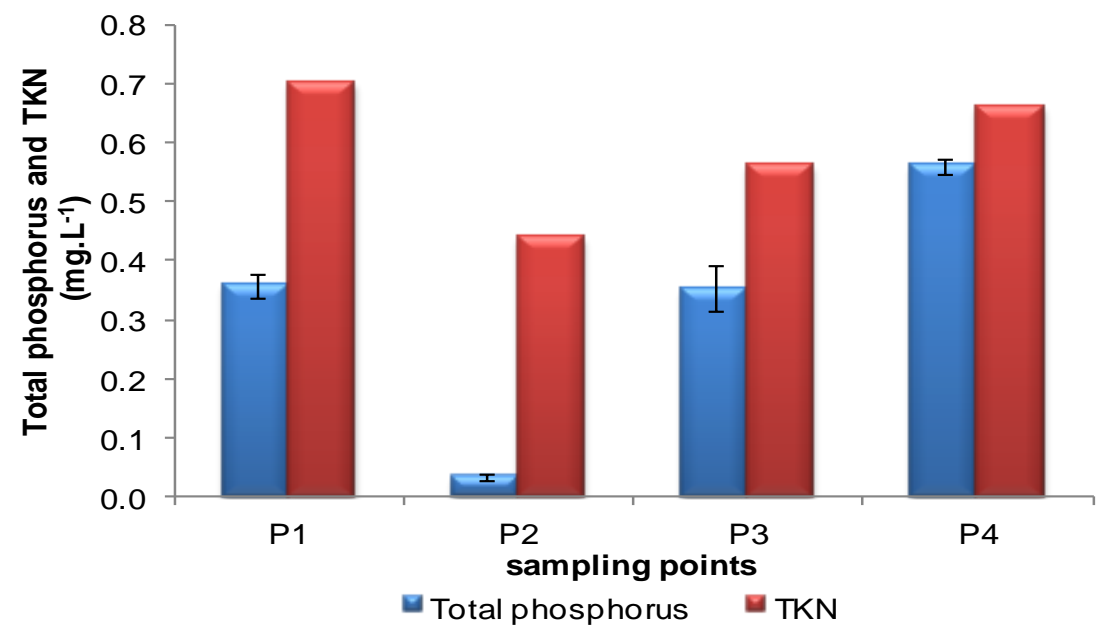

Figure 5 - Concentration of total phosphorus and total Kjeldahl nitrogen along the Tereza Botas creek. 
The Resolution CONAMA n. 357/2005 (BRASIL, 2005) establishes that for Class 2 rivers, the total phosphorus concentration should not be higher than $0.1 \mathrm{mg} . \mathrm{L}^{-1}$. For lentic environments such as points $\mathrm{P} 2$ and $\mathrm{P} 3$ this value should be $0.030 \mathrm{mg} \cdot \mathrm{L}^{-1}$.

The total phosphorus concentration ranged from 0.034 to $0.561 \mathrm{mg} \cdot \mathrm{L}^{-1}$ in the sampled points (Figure 5). These results are all above the legal standards.

At $\mathrm{P} 1$, this result may be related to erosive processes since most soils in Mato Grosso are rich in iron and phosphorus, as well to the presence of organic matter from sewage as observed in loco. At P2, the main cause of the high results is probably the input of nutrients by runoff and due to the soil use in the surroundings of the Jurumirim Tank where small grasslands areas are found. It is worth mentioning that at P2 the phosphorus concentration was not much above the legal limit. Differently to $\mathrm{P} 2$, the main factor causing the elevation of total P concentration is the disposal of domestic untreated wastewaters. Similarly to $\mathrm{P} 1$, the high result at P4 is probably related to the presence of phosphorus in Mato Grosso soil, since there is a discharge of wastewater from the mining upward the sampled point.

Regarding TKN, there is no legal limit in the legislation. Except to $\mathrm{P} 2$, the results of TKN followed the total P, varying from 0.44 to $0.7 \mathrm{mg} \cdot \mathrm{L}^{-1}$. In the P1 and P3 points, the results may be related to the wastewater disposal as observed in loco, as well as to the high density of aquatic macrophytes at P3 that release this nutrient at decomposition. At P2, where the lowest value was observed, there is a lower density of macrophytes and is further upward the urban area with low population. As P4 is localized in a rural area, the high concentration may be due to runoff off cattle raising grasslands.

\subsection{Eletrical conductivity}

Von Sperling (2014) explains that the electrical conductivity refers to the capacity of an aqueous solution to conduct electric current. This capacity depends on the total ion concentration and their mobility, valence, relative concentrations as well as on the water temperature.

Tundisi (1988) pointed out that the presence of riverside vegetation exerts a powerful effect in the absorption of dissolves ions, having a leading role in the reduction in conductivity values.

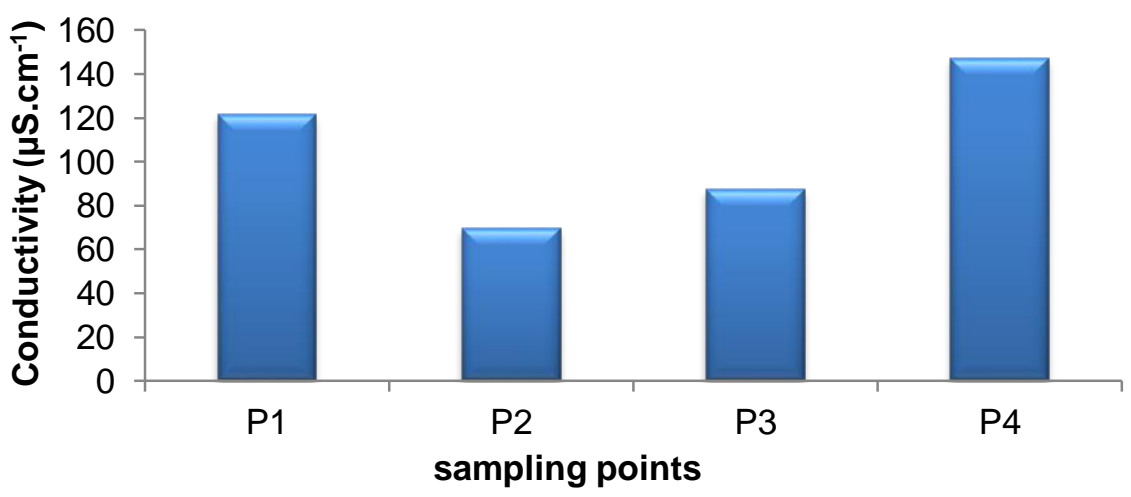

Figure 6 - Variation of water electrical conductivity along Tereza Botas creek, MT. 
Usually, in regions with preserved riverside vegetation the water electrical conductivity, which is an essential indicator of water quality, is very low $\left(<20 \mu \mathrm{S} . \mathrm{cm}^{-1}\right)$. In regions where this vegetation was withdrawn this conductivity is much more elevated $\left(>100 \mu \mathrm{S} . \mathrm{cm}^{-1}\right)$ indicating that the increase in ionic composition of water results from superficial runoff (TUNDISI, 2010). Conductivity values above $100 \mu \mathrm{S} . \mathrm{cm}^{-1}$ may indicate affected ambient as suggested by CETESB (2009).

Conducitity at the sampled points varied from 69.5 to $146.9 \mu \mathrm{S} . \mathrm{cm}^{-1}$ (Figure 6 ). In the field, the high degradation due to the withdrawal of the vegetal coverture at the margins of the water bodies was observed as well as the disposal of untreated domestic wastewater in one of the sampled points (P3). The sampling occurred at the beginning of the rainy season in the region what leads to intensified runoff. The highest values were determined at P1 $\left(121.4 \mu \mathrm{S} . \mathrm{cm}^{-1}\right)$ and P4 (146.9 $\left.\mu \mathrm{S} . \mathrm{cm}^{-1}\right)$ indicating significant impact at these points.

\subsection{True color}

The color of a water sample is associated to the degree of reduction in the intensity of light as it goes through a solution due to absorption of part of the electromagnetic radiation by dissolved solids, mainly organic and inorganic colloidal material. The organic colloids include fulvic and humic acids, natural substances resulting from the partial decomposition of organic compounds present in leaves, among other substrates (CETESB, 2009).

The maximum value for true color established by CONAMA n. 357/2005 (BRASIL, 2005) for Class 2 rivers is $75 \mathrm{mgPt} . \mathrm{L}^{-1}$.

The color values along Tereza Botas creek varied from 77.5 to $288 \mathrm{mgPt} \mathrm{L}^{-1}$ (Figure 7), all of them above the legal limit.

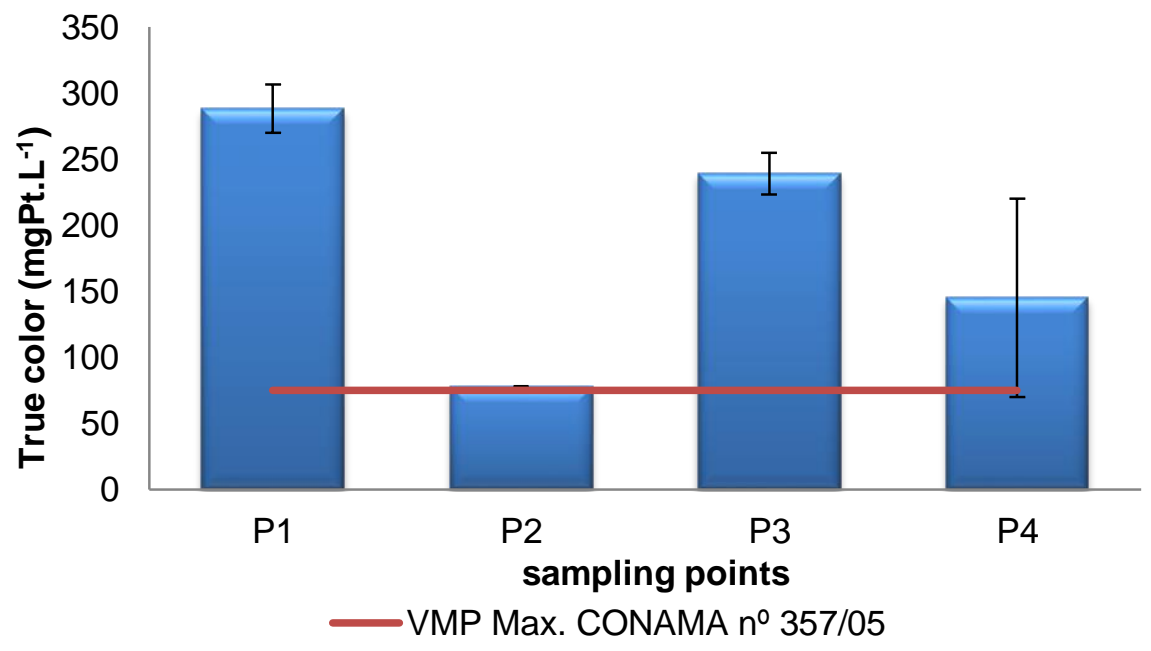

Figure 7 - Variation of true color along Tereza Botas creek, MT.

\subsection{Turbidity}

Water turbidity represents the degree of attenuation in the light intensity that a beam suffers when going through the solution, due to the presence of suspended solids such as inorganic 
particles (sand, silt and clay) and organic detritus such as algae and bacteria, plankton in general among others (CETESB, 2009).

The erosion of river margins in rainy season, which is intensified by inadequate soil management, is an example of phenomenon that results in increased turbidity. Domestic sewage and several industrial effluents also cause elevation in water turbidity. Mining is other activity that causes excessive increases in turbidity leading to the formation of mud banks in the riverbed and alterations in the aquatic ecosystem (CETESB, 2009).

The Resolution CONAMA n. 357/2005 (BRASIL, 2005) determines that water turbidity should not be greater than 100 UNT for Class 2 water bodies. Figure 8 presents the turbidity determined in Tereza Botas creek.

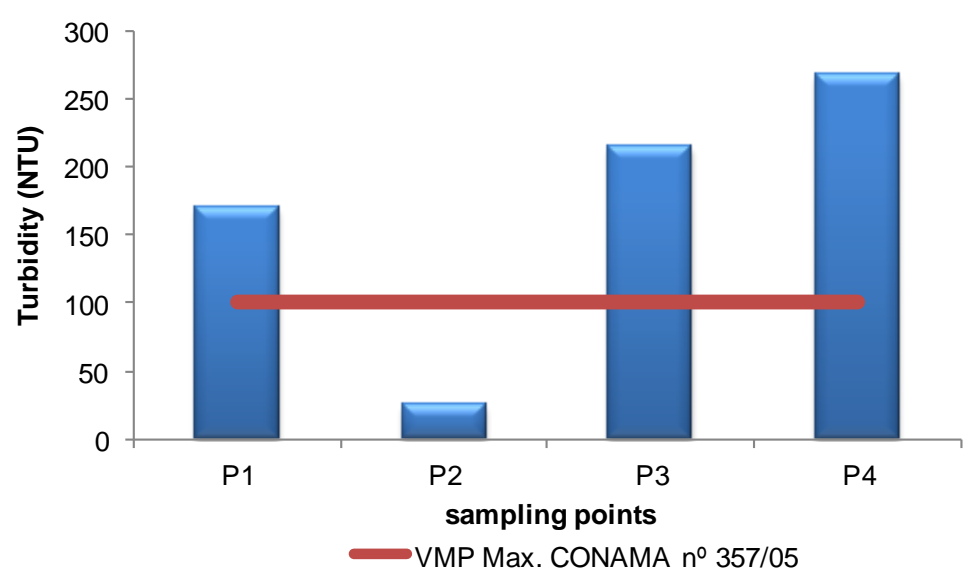

Figure 8 - Variation of turbidity along Tereza Botas creek, MT.

Turbidity values varied from 25.82 to 268 UNT with only one point (P2) within the legal limit. Turbidity in P1 and P3 is probably due to the disposal of domestic sewage as observed in loco. On the other hand, in P4 it is more likely related to the disposal of wastewater from a mining upward this point.

The high turbidity values at P1, P3 and P4 favour the reduction in photosynthesis rate, causing a decreased or even total suppression in productivity and affecting negatively the main water uses.

\subsection{Coliformes totais}

Total coliform are a group of bacteria formed by gram-negative bacillus, aerobic or facultative anaerobic, non-spore forming, oxidase-negative, which are capable of growing in the presence of biliary salts or other surface active compounds with similar properties of growing inhibition and that ferment lactose with the production of acids, aldehydes and gas when incubated at $35-37^{\circ} \mathrm{C}$ from 24 to 48 hours (BETTEGA, 2006).

In the Tereza Botas creek (Figure 9) the presence of total coliforms was observed in all the points along the longitudinal gradient. According to ANVISA n. 275/2002 (BRASIL, 2002) for natural waters the limit is $1.1 \mathrm{MPN} / 100 \mathrm{~mL}$. All the sampled points were well above this limit. 


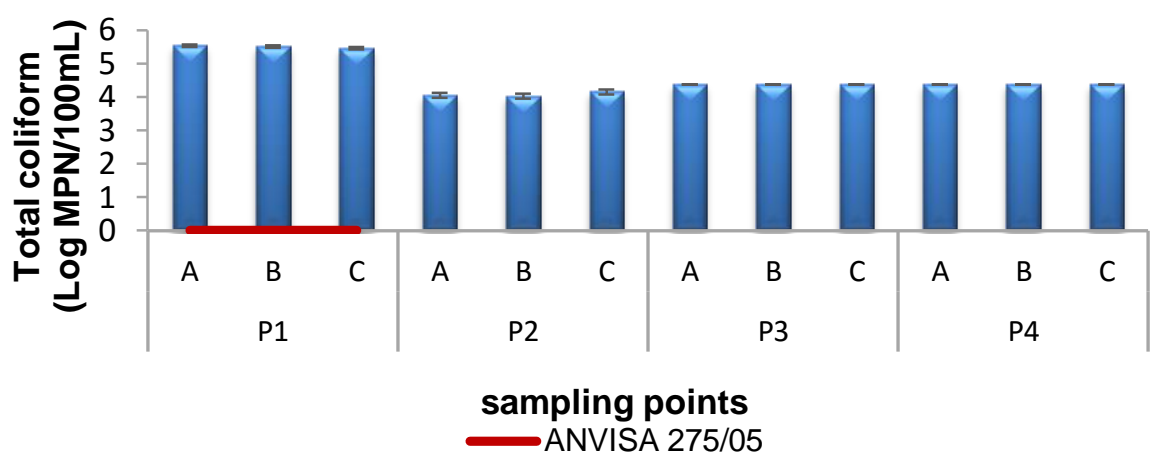

Figure 9 - Variation of concentration of Total coliform in the water samples collected in triplicate along the Tereza Botas creek, MT.

At $P 1$, which is the riverhead, coliform values above $250.000 \mathrm{NMP} / 100 \mathrm{~mL}$ were found, well above the legal limit. At P2, the maximum coliform value was $14.100 \mathrm{NPM} / 100 \mathrm{~mL}$ while at P3 coliform values reached $24.000 \mathrm{NPM} / 100 \mathrm{~mL}$. The point P4 is situated in the rurual area and in its surroundings there mining and cattle raising activies, so the high coliform values are related to animals faeces.

The total coliform group comprises several indicator organisms that live in the intestinal tract of humans and hot blood animals as well as in soil and water. Despite the constant evaluation fo this bacterial group in water quality studies, its determination is less representative of fecal contamination than the thermotolerant coliform or Escherichia coli (SILVA et al., 2005).

\subsubsection{Escherichia coli}

According to Silveira et al. (2009), among the group of coliform bacteria that are present in feces, $95 \%$ are represented by Escherichia coli, which is the main bacteria indicator of fecal contamination whose origin is exclusive of homeothermic animals, indicating recent contamination.

The quantification of $E$. coli in water is of great importance since once detected, it will indicate the probable presence of pathogenic microorganisms which are responsible for waterborne diseases such as typhoid fever, cholera among others. In water streams, this bacterial species indicate pollution by domestic sewage that characterizes the absence of adequate basic sanitation.

Figure 10 presents the results of Escherichia coli in the water of the Tereza Botas creek.

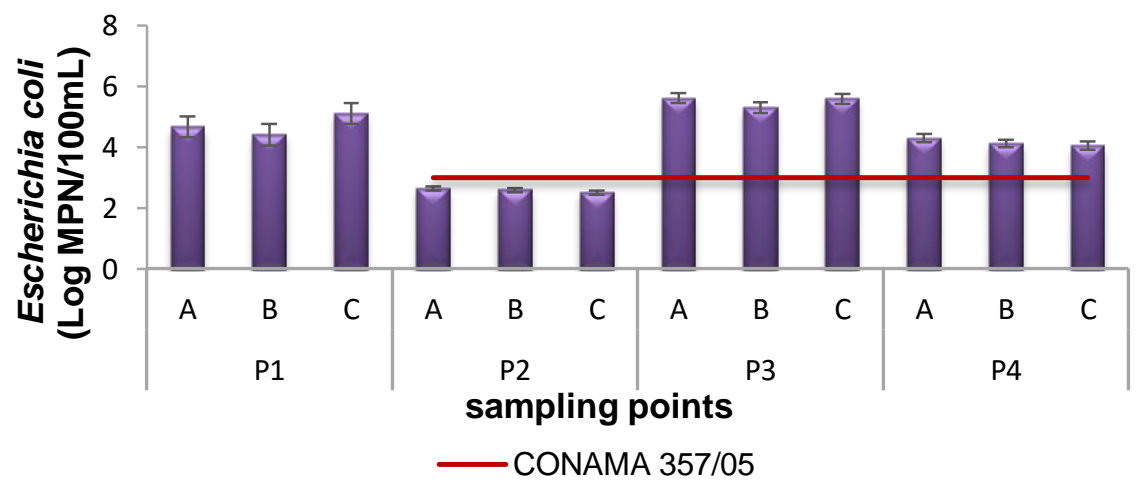

Figure 10 - Variation of the concentration of Escherichia coli in the water samples collected in triplicate along the Tereza Botas creek, MT. 
The occurrence of $E$. coli in the point P1 (riverhead) is in disagreement with the resolution ANVISA n. 275/2005 (BRASIL, 2005), with values above $20.000 \mathrm{NMP} / 100 \mathrm{~mL}$. This result confirms the fecal contamination, which is probably related to the houses with rudimentary cesspits in its surroundings.

The point P2 (average $377 \mathrm{NMP} / 100 \mathrm{~mL}$ ) is the only one which is within the legal standard of Resolution CONAMA N. 357/2005 (BRASIL, 2005) that establishes a limit of $1000 \mathrm{NMP} / 100 \mathrm{~mL}$ for Class 2 rivers, probably due to its localization in a more isolated and natural environment. Also, this corroborates the result of $48 \mathrm{NMP} / 100 \mathrm{~mL}$, emitted by the Consultoria Ambiental Aquanalise in August 2010 for this point.

At $\mathrm{P} 3$, the highest value was detected $(190.000 \mathrm{NMP} / 100 \mathrm{~mL})$ probably from the disposal of domestic sewage at the urban section of the Tereza Botas creek.

In the rural area (P4), the $E$. coli concentrations are in disagreement with the legal limits as a consequence of the surrounding activities (cattle raising and mining) and of the lack of riverside vegetation.

\section{CONCLUSION}

The analyzed limnologic variables indicate great alterations in water quality due to the anthropogenic activities carried out in the Tereza Botas basin. Point P1 (riverehead) is the most critical one. Spatially, the results of all variables were smaller at P2.

OD concentrations and true color confirm the presence of organic matter in decomposition.

Among the evaluated sampled points, $\mathrm{P} 2$ is the only one that is in accordance with the legal standards. This result is related to the localization of this less inhabited region and the absence of sewage disposal.

At P3, an illegal sewage disposal point in the rainwater network was observed which confirmed the microbiological results, endangering the multiple water uses, especially the public water supply and balneability, due to the high E. coli concentration.

All multiple uses were jeopardized in P1 and P3, even when the variables were compared to that of a Class 4 river, which is the class of worst quality.

It was evident that the factor controlling these alterations are the water and soil usage that occur in the microbasin. The inadequate water and soil usage, especially the suppression of riverside vegetation, rudimentary cesspits, disposal of domestic sewage, are responsible for the deterioration of the water quality in this microbasin.

It is important to emphasize the need to recompose the riverside vegetation along the longitudinal gradient of the Tereza Botas creek, elaborate and implement the network of sewage collection and treatment, monitor the water quality in this microbasin in order to render the multiple use viable in accordance with the legal limits. It is especially necessary in P2 (Tank da Rua), an either historically as environmentally important dam, that was used for recreation in the past.

Moreover, the absence of conservationist practices, the still rudimentary planning and management of soil and water usage cooperate to deteriorate the water quality of Bento Gomes River, the only surface water source used for public water supply in Poconé-MT. 


\section{REFERÊNCIAS}

1. APHA - American Public Health Association, AWWA - American Water Works Association, WPCF - Water Pollution Control Federation. Standard Methods for the Analysis of Water and Waste Water. 22 ed., Ed APHA: Washington, 2012.

2. BETTEGA, J. M. P. R; MACHADO, M. R.; PRESIBELLA, M.; BANISKI, G.; BARBOSA, C. A. Métodos analíticos no controle microbiológico de água para consumo humano. Cienc. Agrotec. v. 30, n. 5, p. 950-954, 2006.

3. BRASIL. Resolução CONAMA no. 357 de 17 de Março de 2005. Dispõe sobre as classificações dos corpos d'água e diretrizes ambientais para o seu enquadramento.

4. _ Resolução CONAMA no. 274 de 29 de Novembro de 2000. Revisa os critérios de Balneabilidade em Águas Brasileiras.

5. _ـ Resolução ANVISA RDC n‥ 275 de 22 de Setembro de 2005. Aprova o "Regulamento técnico de características microbiológicas para água mineral natural e água natural"

6. CASARIN, R. Caracterização dos principais vetores de degradação ambiental da bacia hidrográfica Paraguai/Diamantino. Tese de Doutorado em Geografia e Geociências. Programa de Pós-Graduação em Geografia (PPGG), UFRJ, Rio de Janeiro - RJ, 2007. 169p.

7. CASARIN, R. Caracterização dos principais vetores de degradação ambiental da bacia hidrográfica Paraguai/Diamantino. Tese de Doutorado em Geografia e Geociências. Programa de Pós-Graduação em Geografia (PPGG), UFRJ, Rio de Janeiro - RJ, 2007. 169p.

8. COMPANHIA AMBIENTAL DO ESTADO DE SÃO PAULO. Guia nacional de coleta de amostras: água, sedimento, comunidades aquáticas e efluentes líquidos. Organizadores: Carlos Jesus Brandão...(et al.) - São Paulo: CETESB; Brasília: ANA, 2011.

9. COMPANHIA AMBIENTAL DO ESTADO DE SÃO PAULO. Significado ambiental e sanitário das variáveis de qualidade das águas e dos sedimentos e metodologias analíticas e de amostragem. - Série Relatórios. São Paulo: CETESB, 2009, 44 p.

10. ESTEVES, F. A. Fundamentos de limnologia. 3a Ed. Rio de Janeiro: Interciência, 2011. 826p.

11. GONZAGA, L. N.; PAES DE BARROS, L. T. L.; ALMEIDA, N. N.; SILVEIRA, E. A. Mapa de Solos da Região de Poconé/MT: I - Descrição das Unidades. In: SIMPÓSIO SOBRE RECURSOS NATURAIS SÓCIO - ECONÔMICO DO PANTANAL, 3., 2000, Corumbá. Os desafios do novo milênio. Resumos... Corumbá: Embrapa Pantanal, 2000.

12. IBGE. Censo Demográfico, Instituto Brasileiro de Geografia e Estatística, 2010. Disponível em: http://cidades.ibge.gov.br/xtras/perfil.php?lang=\&codmun=510650\&search=matogrossolpocone. Acesso em: out, 2013.

13. Petermann, P. The birds of the Pantanal. In: Junk, W.J., da Silva, C.J., Nunes da Cunha, C. \& Wantzen, K.M. (eds.): The Pantanal: Ecology, biodiversity and sustainable management of a large neotropical seasonal wetland. Sofia-Moscow: Pensoft, p. 523-564, 2011.

14. SILVEIRA, A. et al (Org). Desafios do Saneamento Ambiental. Curso de Capacitação. Cuiabá: Gráfica Print Indústria e Editora Ltda, 2009. 102 p.

15. TUNDISI, J. G.; MATSUMURA-TUNDISI, T. M. Impactos potenciais das alterações do Código Florestal nos recursos hídricos. Biota Neotrop., vol. 10, n. 4, p. 67-76, 2010. 
16. TUNDISI, J. G. Limnologia e Manejo de Represas. Vol. I. São Paulo: Universidade de São Paulo, Escola de Engenharia de são Carlos / CRHEA/ ACIESP, 1988. 506 p.

17. VEIGA, M. M.; FERNANDES, F. R. C. Poconé: um campo de estudos do impacto ambiental do garimpo. Rio de Janeiro: CETEM/CNPq, 1991.

18. VON SPERLING. M. Introdução à qualidade das águas e ao tratamento de esgotos. 4 Ed. Belo Horizonte: Departamento de Engenharia Sanitária - Ambiental. UFMG. 2014. 452 p. 